\title{
QUANTUM CHEMICAL STUDY OF THE RELATIONSHIPS BETWEEN ELECTRONIC STRUCTURE AND PHARMACOKINETIC PROFILE, INHIBITORY STRENGTH TOWARD HEPATITIS C VIRUS NS5B POLYMERASE AND HCV REPLICONS OF INDOLE-BASED COMPOUNDS
}

\author{
AMAYA PAZ DE LA VEGA, DIEGO A. ALARCÓN AND JUAN S. GÓMEZ-JERIA* \\ Quantum Pharmacology Unit, Department of Chemistry, Faculty of Sciences, University of Chile. P.O. Box 653, Santiago, Chile.
}

(Received: April 3, 2013 -Accepted: November 4, 2013)

\begin{abstract}
This paper uses newly developed and extended quantum chemical methods in an attempt to advance the knowledge of the relationship between the variation of several local atomic descriptors of the electronic structure and the variation of the inhibitory capacity of a group of reversible and irreversible inhibitors of hepatitis C virus NS5B polymerase. Good structure-activity relationships were obtained for both kinds of compounds. Some processes are charge-, orbital- and/or steric-controlled. The action mechanisms seem to be different for reversible and irreversible inhibitors. Also, good QSAR equations were obtained for the activities of these compounds in a cellular replicon assay and for pharmacokinetic profiles. The local atomic hardness seems to give a good account of the interaction of the drugs with apolar sites of the partner (enzyme, receptor, etc.). This is the first time that a purely quantum-chemical index is able to deal directly with this kind of interaction.
\end{abstract}

Keywords: Hepatitis C virus, QSAR, NS5B polymerase, Quantum Pharmacology, Quantum Chemistry, HCV replicons.

\section{INTRODUCTION}

Hepatitis $\mathrm{C}$ is a contagious liver disease that results from infection with the hepatitis $\mathrm{C}$ virus (HCV). It can range in severity from a mild illness lasting a few weeks to a serious, lifelong illness. Hepatitis $C$ virus is usually spread when blood from an infected person enters the body of a susceptible person. It is among the most common viruses that infect the liver. Every year, 3-4 million people are infected with HCV. About 150 million people are chronically infected and at risk of developing liver cirrhosis and/or liver cancer. More than 350,000 people die from hepatitis C-related liver diseases every year'. HCV belongs to the genus Hepacivirus and is a member of the family Flaviviridae.

$\mathrm{HCV}$ is a positive-sense single-stranded RNA virus with a single open frame of about 9600 nucleosides ${ }^{2-23}$. The viral genome encodes a polyprotein of more than 3000 amino acids. The polyprotein is divided into structural and nonstructural precursor regions. The structural protein contains the nucleocapsid core protein and two glycoproteins, E1 and E2. The nonstructural proteins located downstream are NS2, NS3, NS4A, NS4B, NS5A and NS5B Because of their essential role in the replication of $\mathrm{HCV}$, intensive research has been focused on finding drugs directly targeting these nonstructural proteins. NS5B has the key function of replicating HCV's RNA by using the viral positive RNA strand as its template, and catalyzes the polymerization of ribonucleoside triphosphates during RNA replication. NS5B has been and remains a major target for the development of HCV-specific drugs ${ }^{24-38}$ (we have included only references from year 2012).

It is of interest then to collect more information, coming from other fields of research, about the physical mechanism(s) underlying NS5B inhibition. We have focused our attention on two recent studies on the inhibition of $\mathrm{HCV}$ NS5B polymerase by several indole-based compounds. The first one deals with irreversible inhibitors and the second one with reversible one ${ }^{39,40}$. This paper uses quantum chemical methods in an attempt to advance the knowledge of the relationship between the variation of several descriptors of the electronic structure and the variation of biological activities for the two abovementioned sets.

\section{METHODS, MODELS AND CALCULATIONS}

\section{The model.}

The conceptual roots of this non-empirical model go back to the work of Agin et al..$^{41}$ and Cammarata et al. ${ }^{42-45}$. Let us consider the state of thermodynamic equilibrium, and a 1:1 stoichiometry in the formation of the drug-receptor complex:

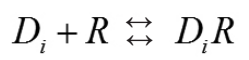

where $D$ is the drug, $R$ is the receptor, and $D R$ is the drug-receptor complex. Starting from the statistical-mechanical definition of the drugreceptor equilibrium constant, and using some satisfactory approximations, it is possible to find a relationship between the equilibrium constant and a set of local atomic reactivity indices belonging only to the drug molecule ${ }^{4-51}$.

$$
\log K_{i}=a+b M_{D_{i}}+c \log \left[\sigma_{D_{i}} /(A B C)^{1 / 2}\right]+d \Delta \varepsilon_{i}
$$

where $K_{i}$ is the equilibrium constant, a, b, c and d are constants, $M$ is the drug's mass, $\sigma$ its symmetry number and $A B C$ the product of the drug's moment of inertia about the three principal axes of rotation. The interaction energy $\Delta \varepsilon_{i}$ cannot be calculated directly due to the size of the receptor. But, as we are dealing with a weak interaction, we can employ Perturbation Theory in the Klopman-Hudson form to evaluate $\Delta \varepsilon_{i}{ }^{52-54}$. According to this method, the change in electron energy, $\Delta \varepsilon$, associated with the interaction of atoms $\mathrm{i}$ and $\mathrm{j}$ is ${ }^{47}$ :

$$
\begin{aligned}
& \Delta \varepsilon \cong \sum_{j}\left[e_{j} Q_{j}+f_{j} S_{j}^{E}+s_{j} S_{j}^{N}\right]+ \\
& +\sum_{j} \sum_{m}\left[h_{j}(m) F_{j}(m)+x_{j}(m) S_{j}^{E}(m)\right]++\sum_{j} \sum_{m^{\prime}}\left[r_{j}\left(m^{\prime}\right) F_{j}\left(m^{\prime}\right)+t_{j}\left(m^{\prime}\right) S_{j}^{N}\left(m^{\prime}\right)\right]+ \\
& +\sum_{j}\left[g_{j} \mu_{j}+k_{j} \eta_{j}+o_{j} \omega_{j}+z_{j} \varsigma_{j}+w_{j} Q_{j}^{\max }\right]
\end{aligned}
$$

where $S_{j}^{E}$ and $S_{j}^{N}$ are, respectively, the total atomic electrophilic (TAESD) and nucleophilic (TANSD) superdelocalizabilities of atom $\mathrm{j}$, $S_{j}^{E}(m)$ is the electrophilic superdelocalizability of atom $\mathrm{j}$ at occupied MO $\mathrm{m}, S^{N}\left(m^{\prime}\right)$ is the nucleophilic superdelocalizability of atom $\mathrm{j}$ at empty MO $\mathrm{m}^{55}$. TAESD is simply the sum over all occupied MOs of $S_{j}^{E}(m)$ and TANSD is the sum over all empty MOs of $S_{j}^{N}\left(m^{\prime}\right)$. These indices are very helpful to compare the reactivity of similar atomic positions through a series of molecules because they include the eigenvalue spectrum which is habitually different in each molecular system. The total atomic electrophilic superdelocalizability is associated with the electron-donor capacity and the total atomic nucleophilic superdelocalizability with the electron-acceptor capacity of a given atom. The last bracket of the right side of Eq. 6 contains new local atomic reactivity indices obtained from the analysis of higher terms of the series expansion for $\Delta \varepsilon_{i}{ }^{51} \cdot \mu_{i}$ , $\eta_{i}, \omega_{i}, \varsigma_{i}$ and $Q_{i}^{\max }$ are, respectively, the local atomic electronic chemical potential of atom i, the local atomic hardness of atom $i$, the local electrophilicty of atom i, the local atomic softness of atom $i$ and the maximal quantity of electronic charge atom $i$ can receive (for the mathematical definitions of the indices see $\left.{ }^{51}\right)$. It is important to notice that these new local atomic reactivity indices (LARIs) are expressed in the same units (i.e., eV) than the global ones and not in $\mathrm{eV} \cdot \mathrm{e}$ as the projected local reactivity indices. For example, $\mu_{i}$ is the total local atomic electronic chemical potential of atom $\mathrm{i}$ : 


$$
\mu_{i}=\frac{E_{o c}^{*}-E_{e m}^{*}}{2}
$$

where $E_{o c}^{*}$ is the upper occupied MO located on atom i with a non-zero Fukui index and $E_{o m}^{*}$ is the lowest empty MO located on atom i with a nonzero Fukui index (i.e., a non-zero electron population). Hereafter we shall use the following nomenclature. HOMO, HOMO-1, LUMO, LUMO+1, etc., refer to the molecule's MOs. Note that in large systems these MOs are not generally located over all the atoms. $\mathrm{HOMO}^{*}$ refers to the highest $\mathrm{MO}$ located on atom $\mathrm{i}$ (that could coincide or not with the molecular HOMO), LUMO* to the lowest MO located on atom i (that could coincide or not with the molecular LUMO), and so on. The insertion of Eq. 3 into Eq. 2 leads to the master equation. Note that the numerical values of the LARIs can be obtained with any quantumchemical calculation (semiempirical, ab initio or DFT).

The moment of inertia term can be expressed in a first approximation as:

$$
\log \left[(A B C)^{-1 / 2}\right] \cong \sum_{t} \sum_{t} m_{i, t} R_{i, t}^{2}=\sum_{t} O_{t}
$$

where the summation over $t$ is over the different substituents of the molecule, $m_{i}$ is the mass of the $\mathrm{i}$-th atom belonging to the $\mathrm{t}$-th substituent, $R_{\text {it }}$ being its distance to the atom to which the substituent is attached. We have called them orientational parameters ${ }^{49}$. This model has shown, beyond all reasonable doubt, that it can shed light on the detailed structure of the drugreceptor interaction for several kind of biomolecules and receptors ${ }^{48,56-66}$, that it has predictive capacity ${ }^{67-69}$ and is even able to detect erroneous experimental data $^{70}$. The last paper employing this method and not belonging to our group was published in $1979^{71}$.

To model in vitro multi-step, multimechanistic drug effects resulting from of two or more unidentified or unsatisfactorily known processes we employed the results of Cammarata et al. relating local atomic reactivity indices with molecular lipophilicity ${ }^{72-74}$. From their results we shall assume that processes such as passing through a membrane, distribution between different phases, etc., can be described in terms of local atomic reactivity indices and orientational parameters. Then, the drug biological activity, $\mathrm{f}(B A)$, should be a similar linear function of the same local atomic reactivity indices than the master equation describing the drug-receptor interaction. Therefore any biological activity can be analyzed simply by replacing $\log K_{i}$ by $\log B A$ in the master equation. This last modeling has a strong restriction: it demands that all members of the whole set of molecules to be analyzed undergo the same steps leading to the apparition of the biological activity. Also, when significant results are obtained and the process is multimechanistic and/or multi-step ${ }^{75}$, the model is not able to assign the results to any particular step. Nevertheless the results can serve as a guide for the experimentalist to optimize a complex biological process. Three previous studies give some support to our model. In the first one, interesting results were obtained for the relationship between accumulation capacity and molecular structure in a group of polychlorinated dibenzo-p-dioxins, polychlorinated dibenzofurans and polychlorinated biphenyls in some zucchini subspecies ${ }^{76}$. In the second one we obtained good quality results concerning structure-biological activity relationships for two different sets of molecules presenting inhibitory activity against some effects of HIV-1 (inhibition of HIV-induced cytopathicity and cytostatic effects) and H1N1 virus (decrease of H1N1-induced cytopathic effects) ${ }^{77}$. In the third one we found relevant structure-activity relationships for the inhibition of HIV-1 WT replication by some phenylaminopyridine derivatives and the inhibition of cell growth by several 1 -azabenzanthrone derivatives ${ }^{75}$. These results seem to suggest that the approach used here is appropriate.

Then, for $\mathrm{n}(\mathrm{i}=1, \mathrm{n})$ molecules we have a set of simultaneous master equations. This system of simultaneous equations holds for the atoms of the molecule directly concerned with the biological activity. Combined with the usual multiple-regression techniques, these equations can be usefully applied to estimate the relative variation of the biological activities in the family of molecules analyzed. We shall work with the common skeleton hypothesis that states that there is a certain group of atoms, common to all molecules analyzed, that accounts for almost all the biological activity. The action of the substituents consists in modifying the electronic structure of this skeleton and/or influencing the correct alignment of the drug through the orientational parameters.
Selection of the experimental data.

Three sets of experimental data were considered here. The first one is the binding affinity (reported as $\log \left(I C_{50}\right)$ ) in an RdRp (RNA-dependent RNA polymerase) assay ${ }^{78}$. The second one is the cell-based replicon assay, reported as $\log \left(E C_{50}\right)^{79}$. The HCV replicon assay is based on a modified viral genome ${ }^{80}$. Cells bearing $\mathrm{HCV}$ replicons are the most used in vitro system for evaluating antiviral agents directed against the $\mathrm{HCV}$ non-structural proteins ${ }^{80}$. The last one is the oral pharmacokinetic (PK) profile reported as $\log (A U C)($ in $\mu \mathrm{M} \cdot \mathrm{h})$. Molecules taken from Ref. 39 form Set I and the ones from Ref. 40 form Set II.

Set I of molecules is shown in Fig. 1 and Table 1. Set II of molecules is shown in Fig. 1 and Table 2. The numbers in Fig. 1 correspond to the common skeleton selected for this study.

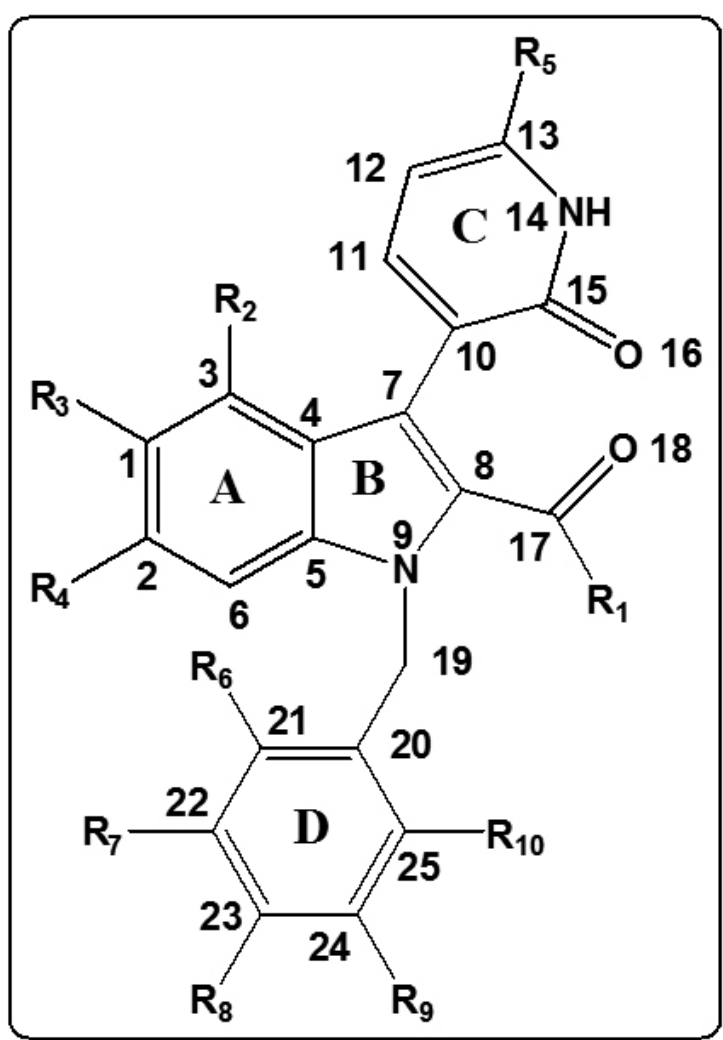

Figure 1. General formula of sets I and II of indole-based inhibitors of HCV NS5B polymerase. Numbers indicate the common skeleton atoms.

\section{CALCULATIONS}

The calculation of the numerical values of the LARIs of Eq. 1 was carried out with Zerner's ZINDO/1 semiempirical method. This choice is right because after geometry optimization this is the only method producing positive nucleophilic superdelocalizabilities as required by the model. Its application gave good results when applied to drug-receptor interaction studies ${ }^{62}$ and biological activities (inhibition of wild-type and drug-resistant HTV-1 reverse transcriptase ${ }^{63}$, accumulation of polychlorinated molecules ${ }^{76}$ and inhibitory activity against some effects of HIV-1 and H1N1 viruses ${ }^{77}$ ). It is worth mentioning that, in general but not always, semiempirical methods give better QSAR results that Hartree-Fock or Density Functional ones ${ }^{65,81}$.

The statistical fitting of equation 1 was performed by means of a Linear Multiple Regression Analysis (LMRA) with the logarithm of the corresponding biological activity value as the dependent variable and the local atomic reactivity indices of the atoms belonging to the common skeleton as independent variables. Hyperchem was employed for quantum-chemical calculations. For multiple regression analysis we used the Statistica software. Orientational parameters for the substituents were calculated as usual ${ }^{49}$. 
Table 1.: Structures and experimental biological activities of set I of indole-based reversible inhibitors of HCV NS5B polymerase ${ }^{\mathrm{a}, \mathrm{b}}$.

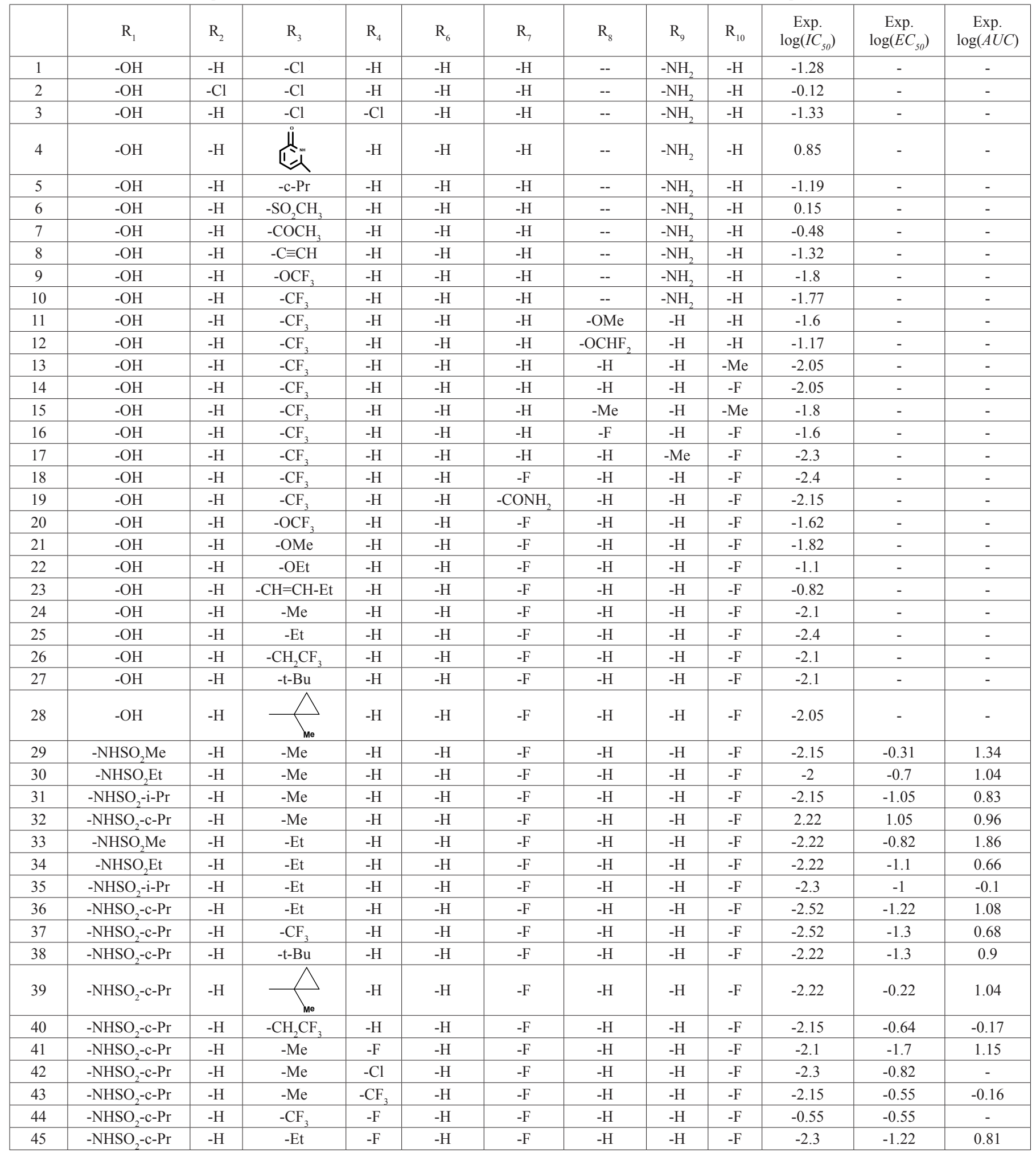

a. $\mathrm{R}_{5}=\mathrm{H}$ in all molecules. $\mathrm{B}$. In molecules $1-10$ the $\mathrm{C}$ atom in position 23 is replaced by a $\mathrm{N}$ atom. 
Table 2.; Structures and experimental biological activities of set II of indole-based irreversible inhibitors of HCV NS5B polymerase ${ }^{\mathrm{a}, \mathrm{b}}$.

\begin{tabular}{|c|c|c|c|c|c|c|c|c|c|c|c|}
\hline Molecule & $\mathrm{R}_{1}$ & $\mathrm{R}_{3}$ & $\mathrm{R}_{4}$ & $\mathrm{R}_{5}$ & $\mathrm{R}_{6}$ & $\mathrm{R}_{7}$ & $\mathrm{R}_{8}$ & $\mathrm{R}_{9}$ & $\mathrm{R}_{10}$ & Exp. $\log \left(I C_{50}\right)$ & Exp. $\log \left(E C_{50}\right)$ \\
\hline $1 \mathrm{a}$ & $-\mathrm{OH}$ & $-\mathrm{Cl}$ & $-\mathrm{H}$ & $-\mathrm{H}$ & $-\mathrm{H}$ & $-\mathrm{NH}_{2}$ & -- & $-\mathrm{H}$ & $-\mathrm{H}$ & 1.72 & 3.68 \\
\hline $2 \mathrm{a}$ & $-\mathrm{NHSO}_{2}$-c-Pr & $-\mathrm{Me}$ & $-\mathrm{H}$ & $-\mathrm{H}$ & $-F$ & $-\mathrm{H}$ & $-\mathrm{H}$ & $-F$ & $-\mathrm{H}$ & 0.78 & 1.95 \\
\hline $3 a$ & $-\mathrm{NHSO}_{2}$-c-Pr & $-\mathrm{Me}$ & $-\mathrm{H}$ & $-\mathrm{H}$ & $-\mathrm{F}$ & $-\mathrm{H}$ & $-\mathrm{H}$ & $-\mathrm{H}$ & $-\mathrm{H}$ & 0.70 & 1.70 \\
\hline $4 \mathrm{a}$ & $-\mathrm{NHSO}_{2}$-c-Pr & $-\mathrm{Me}$ & $-\mathrm{H}$ & $-\mathrm{H}$ & $-F$ & $-\mathrm{Me}$ & $-\mathrm{H}$ & $-\mathrm{H}$ & $-\mathrm{H}$ & 0.60 & 2.58 \\
\hline $5 \mathrm{a}$ & $-\mathrm{NHSO}_{2}-\mathrm{c}-\mathrm{Pr}$ & $-\mathrm{Me}$ & $-\mathrm{H}$ & $-\mathrm{H}$ & $-\mathrm{H}$ & $-\mathrm{NH}_{2}$ & -- & $-\mathrm{H}$ & $-\mathrm{H}$ & 0.78 & 2.70 \\
\hline $6 \mathrm{a}$ & $-\mathrm{NHSO}_{2}$-c-Pr & $-\mathrm{Me}$ & $-\mathrm{H}$ & $-\mathrm{H}$ & $-F$ & $-\mathrm{H}$ & $-\mathrm{H}$ & $-\mathrm{CN}$ & $-\mathrm{H}$ & 0.95 & 2.34 \\
\hline $7 \mathrm{a}$ & $-\mathrm{NHSO}_{2}$-c-Pr & $-\mathrm{Me}$ & $-\mathrm{H}$ & $-\mathrm{H}$ & $-\mathrm{F}$ & $-\mathrm{H}$ & $-\mathrm{H}$ & $-\mathrm{CONH}_{2}$ & $-\mathrm{H}$ & 0.60 & 2.15 \\
\hline $8 a$ & $-\mathrm{NHSO}_{2}$-c-Pr & $-\mathrm{Me}$ & $-\mathrm{H}$ & $-\mathrm{H}$ & $-F$ & $-\mathrm{H}$ & $-\mathrm{H}$ & $-\mathrm{SO}_{2} \mathrm{Me}$ & $-\mathrm{H}$ & 0.70 & 2.76 \\
\hline $9 \mathrm{a}$ & $-\mathrm{NHSO}_{2}$-c-Pr & $-\mathrm{Me}$ & $-\mathrm{H}$ & $-\mathrm{H}$ & $-F$ & $-\mathrm{H}$ & $-\mathrm{H}$ & $-\mathrm{SO}_{2} \mathrm{NH}_{2}$ & $-\mathrm{H}$ & 0.70 & 2.74 \\
\hline $10 \mathrm{a}$ & $-\mathrm{NHSO}_{2}-\mathrm{c}-\mathrm{Pr}$ & $-\mathrm{Me}$ & $-\mathrm{H}$ & $-\mathrm{H}$ & $-\mathrm{F}$ & $-\mathrm{CN}$ & $-\mathrm{H}$ & $-\mathrm{SO}_{2} \mathrm{Me}$ & $-\mathrm{H}$ & 0.48 & 0.70 \\
\hline $11 \mathrm{a}$ & $-\mathrm{NHSO}_{2}$-c-Pr & $-\mathrm{Me}$ & $-\mathrm{H}$ & $-\mathrm{H}$ & $-\mathrm{Cl}$ & $-\mathrm{H}$ & $-\mathrm{H}$ & $-\mathrm{SO}_{2} \mathrm{CF}_{3}$ & $-\mathrm{H}$ & 1.66 & 2.95 \\
\hline $12 \mathrm{a}$ & $-\mathrm{NHSO}_{2}$-c-Pr & $-\mathrm{Me}$ & $-\mathrm{H}$ & $-\mathrm{H}$ & $-\mathrm{Cl}$ & $-\mathrm{H}$ & $-\mathrm{H}$ & $-\mathrm{SOCF}_{3}$ & $-\mathrm{H}$ & 1.15 & 3.53 \\
\hline $13 \mathrm{a}$ & $-\mathrm{NHSO}_{2}$-c-Pr & $-\mathrm{Me}$ & $-\mathrm{H}$ & $-\mathrm{H}$ & $-F$ & $-\mathrm{SO}_{2} \mathrm{Me}$ & $-\mathrm{H}$ & $-F$ & $-F$ & 1.15 & 2.43 \\
\hline $14 \mathrm{a}$ & $-\mathrm{NHSO}_{2}$-c-Pr & $-E t$ & $-\mathrm{H}$ & $-\mathrm{H}$ & $-F$ & $-\mathrm{H}$ & $-\mathrm{Cl}$ & $-\mathrm{SO}_{2} \mathrm{Me}$ & $-\mathrm{H}$ & 0.30 & 1.78 \\
\hline $15 \mathrm{a}$ & $-\mathrm{NHSO}_{2}$-c-Pr & -Et & $-\mathrm{H}$ & $-\mathrm{H}$ & $-F$ & $-\mathrm{H}$ & $-\mathrm{CN}$ & $-\mathrm{SO}_{2} \mathrm{Me}$ & $-H$ & 0.48 & 0.48 \\
\hline $16 \mathrm{a}$ & $-\mathrm{NHSO}_{2}$-c-Pr & $-E t$ & $-\mathrm{H}$ & $-\mathrm{H}$ & $-\mathrm{Cl}$ & $-\mathrm{H}$ & $-\mathrm{Cl}$ & $-\mathrm{SO}_{2} \mathrm{NH}_{2}$ & $-\mathrm{H}$ & 0.78 & 3.15 \\
\hline $17 \mathrm{a}$ & $-\mathrm{NHSO}_{2}$-c-Pr & $-\mathrm{Me}$ & $-\mathrm{H}$ & $-\mathrm{H}$ & $-F$ & $-F$ & $-\mathrm{H}$ & $-\mathrm{CONH}_{2}$ & $-F$ & 1.15 & 3.52 \\
\hline $18 \mathrm{a}$ & $-\mathrm{NHSO}_{2}$-c-Pr & $-\mathrm{Me}$ & $-\mathrm{H}$ & $-\mathrm{H}$ & $-\mathrm{Cl}$ & $-\mathrm{H}$ & $-\mathrm{H}$ & $-\mathrm{NO}_{2}$ & $-\mathrm{H}$ & 0.85 & 1.20 \\
\hline $19 \mathrm{a}$ & $-\mathrm{NHSO}_{2}$-c-Pr & $-\mathrm{Me}$ & $-\mathrm{H}$ & $-\mathrm{H}$ & $-F$ & $-\mathrm{H}$ & $-\mathrm{H}$ & $-\mathrm{NO}_{2}$ & $-\mathrm{H}$ & 0.78 & 0.00 \\
\hline $20 \mathrm{a}$ & $-\mathrm{OH}$ & $-\mathrm{Me}$ & $-\mathrm{H}$ & $-\mathrm{H}$ & $-F$ & $-\mathrm{H}$ & $-\mathrm{H}$ & $-\mathrm{NO}_{2}$ & $-\mathrm{H}$ & 0.48 & 0.00 \\
\hline $21 \mathrm{a}$ & $-\mathrm{NHSO}_{2} \mathrm{Me}$ & $-\mathrm{Me}$ & $-\mathrm{H}$ & $-\mathrm{H}$ & $-F$ & $-\mathrm{H}$ & $-\mathrm{H}$ & $-\mathrm{NO}_{2}$ & $-\mathrm{H}$ & 0.78 & 0.00 \\
\hline $22 \mathrm{a}$ & $-\mathrm{NHSO}_{2}-\mathrm{i}-\mathrm{Pr}$ & $-\mathrm{Me}$ & $-\mathrm{H}$ & $-\mathrm{H}$ & $-F$ & $-\mathrm{H}$ & $-\mathrm{H}$ & $-\mathrm{NO}_{2}$ & $-\mathrm{H}$ & 0.60 & 0.48 \\
\hline $23 a$ & -NHSO-i-Pr & $-\mathrm{Me}$ & $-\mathrm{H}$ & $-\mathrm{H}$ & $-F$ & $-\mathrm{H}$ & $-\mathrm{H}$ & $-\mathrm{NO}_{2}$ & $-\mathrm{H}$ & 0.85 & 0.30 \\
\hline $24 \mathrm{a}$ & $-\mathrm{NHSO}_{2} \mathrm{~N}(\mathrm{Me})_{2}$ & $-\mathrm{Me}$ & $-\mathrm{H}$ & $-\mathrm{H}$ & $-F$ & $-\mathrm{H}$ & $-\mathrm{H}$ & $-\mathrm{NO}_{2}$ & $-\mathrm{H}$ & 0.70 & -0.30 \\
\hline $25 \mathrm{a}$ & $-\mathrm{OH}$ & $-\mathrm{Me}$ & $-\mathrm{H}$ & $-\mathrm{Me}$ & $-F$ & $-\mathrm{H}$ & $-\mathrm{H}$ & $-\mathrm{NO}_{2}$ & $-\mathrm{H}$ & 1.11 & 1.48 \\
\hline $26 \mathrm{a}$ & $-\mathrm{NHSO}_{2} \mathrm{Me}$ & $-\mathrm{Me}$ & $-\mathrm{H}$ & $-\mathrm{Me}$ & $-F$ & $-\mathrm{H}$ & $-\mathrm{H}$ & $-\mathrm{NO}_{2}$ & $-\mathrm{H}$ & 0.78 & 0.90 \\
\hline $27 \mathrm{a}$ & $-\mathrm{NHSO}_{2}$-c-Pr & $-\mathrm{Me}$ & $-\mathrm{H}$ & $-\mathrm{Me}$ & $-\mathrm{F}$ & $-\mathrm{H}$ & $-\mathrm{H}$ & $-\mathrm{NO}_{2}$ & $-\mathrm{H}$ & 1.08 & 0.95 \\
\hline $28 \mathrm{a}$ & $-\mathrm{NHSO}_{2}$-c-Pr & $-F$ & $-\mathrm{H}$ & $-\mathrm{H}$ & $-F$ & $-\mathrm{H}$ & $-\mathrm{H}$ & $-\mathrm{NO}_{2}$ & $-\mathrm{H}$ & 0.70 & 0.78 \\
\hline $29 \mathrm{a}$ & $-\mathrm{NHSO}_{2}$-c-Pr & $-\mathrm{H}$ & $-\mathrm{H}$ & $-\mathrm{H}$ & $-\mathrm{F}$ & $-\mathrm{H}$ & $-\mathrm{H}$ & $-\mathrm{NO}_{2}$ & $-\mathrm{H}$ & 0.60 & 0.78 \\
\hline $30 \mathrm{a}$ & $-\mathrm{NHSO}_{2}-\mathrm{c}-\mathrm{Pr}$ & $-\mathrm{Cl}$ & $-\mathrm{H}$ & $-\mathrm{H}$ & $-F$ & $-\mathrm{H}$ & $-\mathrm{H}$ & $-\mathrm{NO}_{2}$ & $-\mathrm{H}$ & 0.78 & 0.70 \\
\hline $31 \mathrm{a}$ & $-\mathrm{NHSO}_{2}-\mathrm{c}-\mathrm{Pr}$ & $-\mathrm{CF}_{3}$ & $-\mathrm{H}$ & $-\mathrm{H}$ & $-F$ & $-\mathrm{H}$ & $-\mathrm{H}$ & $-\mathrm{NO}_{2}$ & $-\mathrm{H}$ & 0.60 & 0.30 \\
\hline $32 a$ & $-\mathrm{NHSO}_{2}$-c-Pr & $-\mathrm{t}-\mathrm{Bu}$ & $-\mathrm{H}$ & $-\mathrm{H}$ & $-\mathrm{F}$ & $-\mathrm{H}$ & $-\mathrm{H}$ & $-\mathrm{NO}_{2}$ & $-\mathrm{H}$ & 0.78 & 1.00 \\
\hline $33 a$ & $-\mathrm{NHSO}_{2}-\mathrm{c}-\mathrm{Pr}$ & $-E t$ & $-\mathrm{H}$ & $-\mathrm{H}$ & $-F$ & $-\mathrm{H}$ & $-\mathrm{H}$ & $-\mathrm{NO}_{2}$ & $-\mathrm{H}$ & 0.60 & 0.00 \\
\hline $34 \mathrm{a}$ & $-\mathrm{NHSO}_{2}$-c-Pr & $-\mathrm{Me}$ & $-F$ & $-\mathrm{H}$ & $-F$ & $-\mathrm{H}$ & $-\mathrm{H}$ & $-\mathrm{NO}_{2}$ & $-\mathrm{H}$ & 0.85 & 0.60 \\
\hline $35 \mathrm{a}$ & $-\mathrm{OH}$ & $-E t$ & $-\mathrm{H}$ & $-\mathrm{H}$ & $-F$ & $-\mathrm{H}$ & $-\mathrm{H}$ & $-\mathrm{NO}_{2}$ & $-\mathrm{H}$ & --- & 0.00 \\
\hline
\end{tabular}

a. $\mathrm{R}_{2}=\mathrm{H}$ in all molecules. $\mathrm{b}$. In molecules $1 \mathrm{a}$ and $5 \mathrm{a}$ the $\mathrm{C}$ atom in position 23 is replaced by a nitrogen atom.

\section{RESULTS}

Results for the RdRp (RNA-dependent RNA polymerase) assay for Set I (reversible inhibitors).

A preliminary LMRA showed that for molecule 9 the corresponding standard residual fell outside the $\pm 2 \sigma$ limit. Therefore this molecule was excluded from the final LMRA. The best equation obtained was:

$\log I C_{50}=-1.68-0.63 S_{24}^{\Sigma}(\text { HOMO }-1)^{*}-7.47 Q_{5}+S_{12}^{N}(\text { LUMO }+1)^{*}+3.78 F_{5}(\text { HOMO })^{*}+$

$\left.+0.001 \phi_{8}-0.34 S_{17}^{\mathrm{N}}(L U M O)\right)^{*}$ with $\mathrm{n}=44, \mathrm{R}=0.97, \mathrm{R}^{2}=0.95$, adj. $\mathrm{R}^{2}=0.94, \mathrm{~F}(6,37)=107.44(\mathrm{p}$ $<0.00001$ ), outliers $>2 \sigma=0$ and $\mathrm{SD}=0.19$. Here, $\varphi_{8}$ is the orientational effect of the $\mathrm{R}_{8}$ substituent, $Q_{5}$ is the net charge of atom 5, $S_{24}{ }^{E}(H O M O-1)^{*}$ is the local atomic electrophilic superdelocalizability of atom 24 (see Fig. 1 for atom numbering) at its second highest occupied MO with nonzero electron population, $S_{12}^{N}(L U M O+1) *$ is the local atomic nucleophilic superdelocalizability of atom 12 at its second empty $\mathrm{MO}$ with non-zero electron population, $F_{5}(H O M O) *$ is the Fukui index of atom 5 at its highest occupied $\mathrm{MO}$ and $S^{N}(L U M O) *$ is the local atomic nucleophilic superdelocalizability of atom 17 at its first empty MO. Regarding independent variables, there are no significant internal correlations at $p<0.05$. The beta coefficients and 
t-test for significance of coefficients of Eq. 6 are shown in Table 3. Figure 2 shows the plot of observed values vs. calculated ones. The associated statistical parameters of Eq. 6 show that this equation is statistically significant, and that the variation of LARIs belonging to the common skeleton explains about $94 \%$ of the variation of the inhibitory activity. 6.

Table 3.: Beta coefficients and t-test for significance of coefficients in Eq.

\begin{tabular}{|c|c|c|c|}
\hline Variable & Beta & $\mathrm{t}$ & $\mathrm{p}$ \\
\hline $\mathrm{S}_{24}{ }^{\mathrm{E}}(\mathrm{HOMO}-2)^{*}$ & -0.61 & -13.98 & $<0.0000001$ \\
\hline $\mathrm{Q}_{5}$ & -0.49 & -10.17 & $<0.0000001$ \\
\hline $\mathrm{S}_{12}{ }^{\mathrm{N}}(\mathrm{LUMO}+1)^{*}$ & 0.15 & 4.47 & $<0.002$ \\
\hline $\mathrm{F}_{5}(\mathrm{HOMO})^{*}$ & 0.24 & 6.21 & $<0.0000001$ \\
\hline$\phi_{8}$ & 0.18 & 4.06 & $<0.0002$ \\
\hline $\mathrm{S}_{4}{ }^{\mathrm{N}}(\mathrm{LUMO}) *$ & -0.16 & -3.56 & $<0.001$ \\
\hline
\end{tabular}

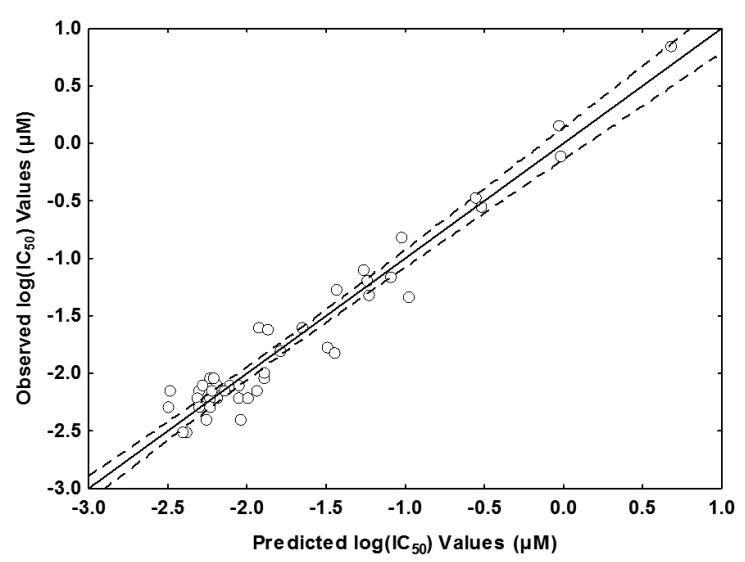

Figure 2. Plot of predicted vs. observed $\log \left(\mathrm{IC}_{50}\right)$ values from Eq. 6 . Dashed lines denote the $95 \%$ confidence interval.

Results for the cell-based replicon assay for set I (reversible inhibitors). The best equation obtained was:

$\log \left(E C_{50}\right)=-16.59+9.09 \eta_{5}+28.20 \eta_{14}+1.02 F_{12}(L U M O+1)^{*}-1.77 F_{22}($ HOMO $) *$

with $\mathrm{n}=17, \mathrm{R}=0.93, \mathrm{R}^{2}=0.87$, adj $\mathrm{R}^{2}=0.83, \mathrm{~F}(4,12)=20.77(\mathrm{p}<$ 0.00003 ), outliers $>2 \sigma=0$ and $\mathrm{SD}=0.16$. Here $\eta_{5}$ and $\eta_{14}$ are, respectively, the local atomic hardnesses of atoms 5 and 14. $F_{12}(L U M O+1) *$ is the Fukui index of atom 12 at the second empty MO located on it and $F_{22}(H O M O) *$ is the Fukui index of atom 22 at the highest occupied MO located on it (see Figure 1 for atom numbering). Regarding independent variables, there are no significant internal correlations at $\mathrm{p}<0.05$. The beta coefficients and t-test for significance of coefficients of Eq. 7 are shown in Table 4. Figure 3 shows the plot of observed values $v$ s. calculated ones. The associated statistical parameters of Eq. 7 show that this equation is statistically significant and the variation of LARIs belonging to the common skeleton explains about $83 \%$ of the variation of the inhibitory activity.

Table 4.: Beta coefficients and t-test for significance of coefficients in Eq. 7.

\begin{tabular}{|c|c|c|c|}
\hline Variable & Beta & $\mathrm{t}$ & $\mathrm{p}$ \\
\hline$\eta_{5}$ & 0.69 & 5.64 & $<0.0001$ \\
\hline$\eta_{14}$ & 0.77 & 6.18 & $<0.00005$ \\
\hline $\mathrm{F}_{12}(\mathrm{LUMO}+1)^{*}$ & 0.47 & 3.90 & $<0.002$ \\
\hline $\mathrm{F}_{22}(\mathrm{HOMO})^{*}$ & -0.33 & -3.03 & $<0.01$ \\
\hline
\end{tabular}

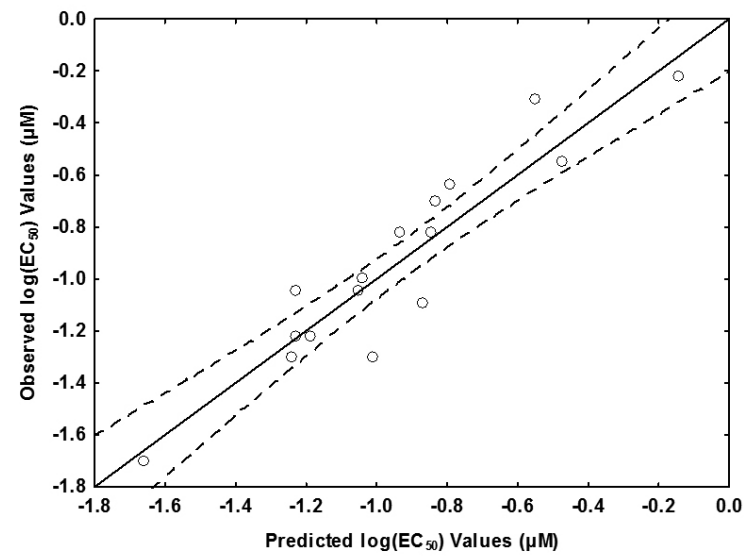

Figure 3. Plot of predicted vs. observed $\log \left(E C_{50}\right)$ values from Eq. 7. Dashed lines denote the $95 \%$ confidence interval.

Results for the pharmacokinetic properties of set I (reversible inhibitors).

A preliminary LMRA showed that for molecule 3 the corresponding standard residual fell outside the $\pm 2 \sigma$ limit. Therefore this molecule was excluded from the final LMRA. The best equation obtained was:

$$
\begin{aligned}
& \log (A U C)=-6.04+44.07 F_{15}(L U M O+1) *-6.63 F_{6}(L U M O+2)^{*}+ \\
& +3.17 \eta_{23}-0.98 F_{25}(H O M O-2) *
\end{aligned}
$$

with $\mathrm{n}=14, \mathrm{R}=0.98, \mathrm{R}^{2}=0.96$, adj $\mathrm{R}^{2}=0.94, \mathrm{~F}(4,9)=52.70(\mathrm{p}<0.000001)$, outliers $>2 \sigma=0$ and $\mathrm{SD}=0.14$. Here, $\eta_{23}$ is the local atomic hardness of atom 23 (see Figure 1 for atom numbering). The remaining terms have analogous meanings as the similar ones explained in Eqs. 6 and 7. Regarding independent variables, there are no significant internal correlations at $p<0.05$. The beta coefficients and t-test for significance of coefficients of Eq. 8 are shown in Table 5. Figure 4 shows the plot of observed values vs. calculated ones. The associated statistical parameters of Eq. 8 show that this equation is statistically significant and that the variation of LARIs belonging to the common skeleton explains about $94 \%$ of the variation of the pharmacokinetic profile.

Table 5.: Beta coefficients and t-test for significance of coefficients in Eq.

\begin{tabular}{|c|c|c|c|}
\hline Variable & Beta & $\mathrm{t}(9)$ & $\mathrm{p}$ \\
\hline $\mathrm{F}_{15}(\mathrm{LUMO}+1)^{*}$ & 1.07 & 12.35 & $<0.000001$ \\
\hline $\mathrm{F}_{6}(\mathrm{LUMO}+2)^{*}$ & -0.57 & -7.50 & $<0.00004$ \\
\hline$\eta_{23}$ & 0.18 & 2.51 & $<0.03$ \\
\hline $\mathrm{F}_{25}(\mathrm{HOMO}-2)^{*}$ & -0.18 & -2.41 & $<0.04$ \\
\hline
\end{tabular}

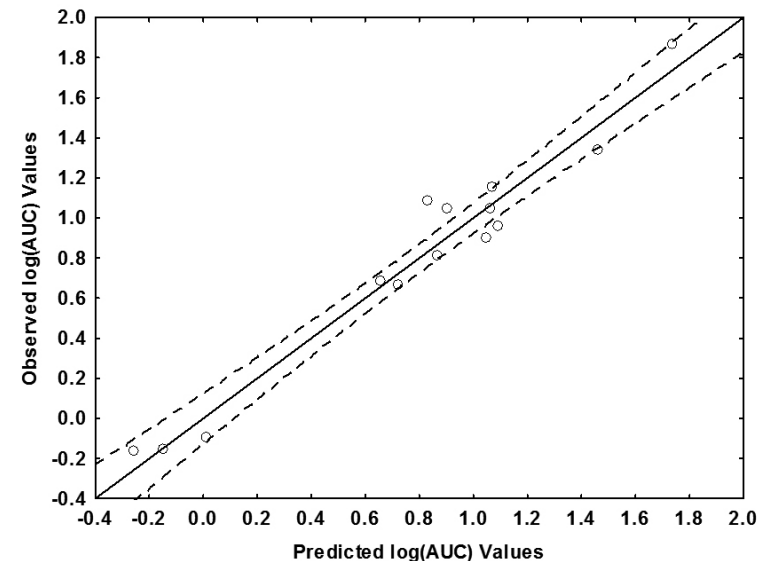

Figure 4. Plot of predicted vs. observed $\log (A U C)$ values from Eq. 8 . Dashed lines denote the $95 \%$ confidence interval. 
Results of the RdRp (RNA-dependent RNA polymerase) assay for Set II (irreversible inhibitors).

A preliminary LMRA showed that for molecules 1a and 11a the corresponding standard residuals fell outside the $\pm 2 \sigma$ limit. Therefore these molecules were excluded from the final LMRA. The best equation obtained was:

$$
\begin{aligned}
& \log \left(I C_{50}\right)=0.61+0.18 S_{21}^{N}(L U M O)^{*}+0.009 \varphi_{4}+0.01 \varphi_{10}- \\
& -0.16 S_{21}^{N}(L U M O+2)^{*}+0.63 F_{20}(L U M O+2)^{*}
\end{aligned}
$$

with $\mathrm{n}=32, \mathrm{R}=0.87, \mathrm{R}^{2}=0.76$, adj. $\mathrm{R}^{2}=0.72, \mathrm{~F}(5,26)=16.58(\mathrm{p}<$ 0.000001 ), outliers $>2 \sigma=0$ and $\mathrm{SD}=0.11$. Here, $\varphi_{4}$ and $\varphi_{10}$ are, respectively, the orientational parameters of the $\mathrm{R}_{4}$ and $\mathrm{R}_{10}$ substituents (see Figure 1 for atom numbering). Regarding independent variables, there are no significant internal correlations at $\mathrm{p}<0.05$. The beta coefficients and $\mathrm{t}$-test for significance of coefficients of Eq. 9 are shown in Table 6. Figure 5 shows the plot of observed values $v s$. calculated ones. The associated statistical parameters of Eq. 9 show that this equation is statistically significant and that the variation of LARIs belonging to the common skeleton explains about the $72 \%$ of the variation of the inhibitory activity.

Table 6.: Beta coefficients and t-test for significance of coefficients in Eq.

\begin{tabular}{|c|c|c|c|}
\hline Variable & Beta & $\mathrm{t}(26)$ & $\mathrm{p}$ \\
\hline $\mathrm{S}_{21}{ }^{\mathrm{N}}(\mathrm{LUMO}) *$ & 0.30 & 2.90 & $<0.007$ \\
\hline$\phi_{4}$ & 0.49 & 4.32 & $<0.0002$ \\
\hline$\phi_{10}$ & 0.63 & 5.53 & $<0.000008$ \\
\hline $\mathrm{S}_{21}{ }^{\mathrm{N}}(\mathrm{LUMO}+2)^{*}$ & -0.75 & -5.19 & $<0.00002$ \\
\hline $\mathrm{F}_{20}(\mathrm{LUMO}+2)^{*}$ & 0.53 & 3.90 & $<0.0006$ \\
\hline
\end{tabular}

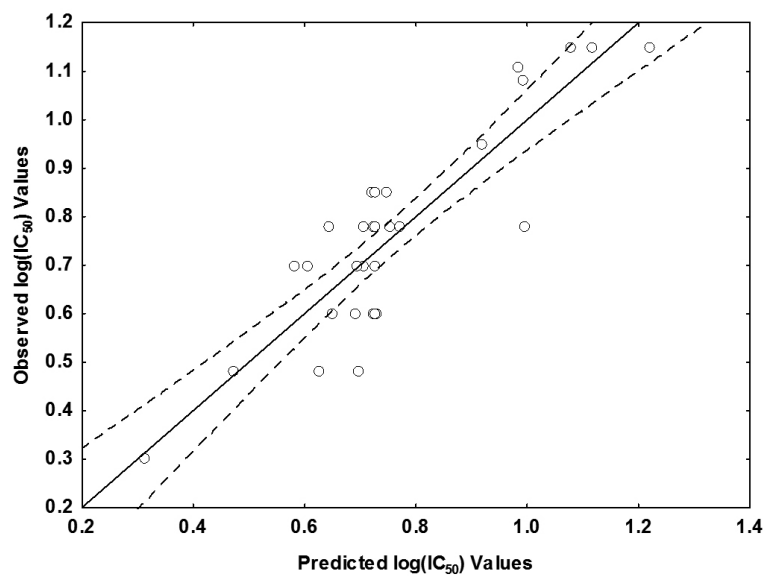

Figure 5. Plot of predicted $v s$. observed $\log \mathrm{IC}_{50}$ values from Eq. 9. Dashed lines denote the $95 \%$ confidence interval.

Results for the cell-based replicon assay for set II (irreversible inhibitors).

Preliminary LMRAs showed that for molecules 33a, 36a, 37a and 45a the corresponding standard residuals fell outside the $\pm 2 \sigma$ limit. Therefore these molecules were excluded from the final LMRA. The best equation obtained was:

$$
\log (E C 50)=7.47-230.69 \omega_{24}+0.51 S_{1}^{N}(L U M O) *+1.61 S_{14}^{N}(L U M O+1)^{*}+0.07 \varphi_{10}-
$$$$
-6.62 F_{18}(H O M O-1) *-0.92 S_{13}^{N}-0.01 \varphi_{8}-12.03 \eta_{11}+1.65 F_{1}(L U M O+2) *
$$

with $\mathrm{n}=31, \mathrm{R}=0.98, \mathrm{R}^{2}=0.97$, adj. $\mathrm{R}^{2}=0.95, \mathrm{~F}(9,21)=67.74(\mathrm{p}<$ 0.000001 ), outliers $>2 \sigma=0$ and $\mathrm{SD}=0.26$. Here, $\omega_{24}$ is the local atomic electrophilicity of atom $24, \eta_{\mu}$ is the local atomic hardness of atom 11 , and $\varphi_{8}$ and $\varphi_{10}$ are the orientational effects of substituents $\mathrm{R}_{8}$ and $\mathrm{R}_{10}$ (see Figure 1 for atom numbering). Regarding independent variables, there are no significant internal correlations at $\mathrm{p}<0.05$. The beta coefficients and t-test for significance of coefficients of Eq. 10 are shown in Table 7. Figure 6 shows the plot of observed values $v s$. calculated ones. The associated statistical parameters of Eq. 10 show that this equation is statistically significant and that the variation of LARIs belonging to the common skeleton explains about $95 \%$ of the variation of the inhibitory activity.

Table 7.: Beta coefficients and t-test for significance of coefficients in Eq 10.

\begin{tabular}{|c|c|c|c|}
\hline Variable & Beta & $\mathrm{t}(21)$ & $\mathrm{p}$ \\
\hline$\omega_{24}$ & -0.62 & -13.86 & $<0.0000001$ \\
\hline $\mathrm{S}_{1}{ }^{\mathrm{N}}(\mathrm{LUMO})^{*}$ & 0.28 & 5.63 & $<0.000001$ \\
\hline $\mathrm{S}_{14}{ }^{\mathrm{N}}(\mathrm{LUMO}+1)^{*}$ & 0.45 & 10.52 & $<0.0000001$ \\
\hline$\varphi_{10}$ & 0.59 & 9.46 & $<0.0000001$ \\
\hline $\mathrm{F}_{18}(\mathrm{HOMO}-1)^{*}$ & -0.34 & -7.37 & $<0.0000001$ \\
\hline $\mathrm{S}_{13}{ }^{\mathrm{N}}$ & -0.30 & -6.27 & $<0.000003$ \\
\hline$\varphi_{8}$ & -0.38 & -6.13 & $<0.000004$ \\
\hline$\eta_{11}$ & -0.26 & -5.99 & $<0.000006$ \\
\hline $\mathrm{F}_{1}(\mathrm{LUMO}+2)^{*}$ & 0.27 & 5.95 & $<0.000007$ \\
\hline
\end{tabular}

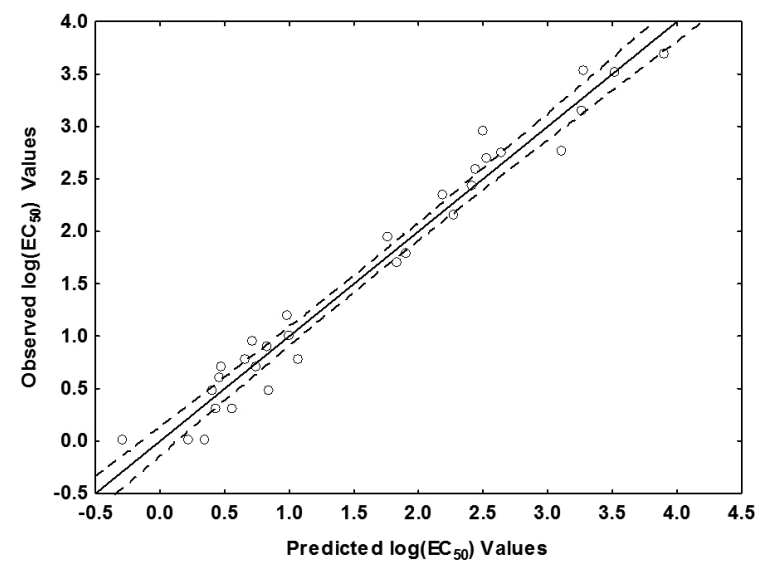

Figure 6. Plot of predicted vs. observed $\log \left(\mathrm{EC}_{50}\right)$ values from Eq. 10. Dashed lines denote the $95 \%$ confidence interval.

\section{DISCUSSION}

One of the most important aspects to keep in mind for the following discussion is that rings A-B, C and D are not coplanar. Figure 7 shows a typical three dimensional (3D) skeleton of the systems studied here. Therefore, when we present two dimensional (2D) pharmacophores below, the reader must remember this fact. The main reason to use 2D instead of 3D representations is that we do not have enough information to decide, in the case of an aromatic interaction, from what side it occurs.

\section{Analysis of the RdRp (RNA-dependent RNA polymerase) assay results} for Set I (reversible inhibitors).

The analysis of Eq. 6 and the Beta coefficients of Table 3 shows that the variation of the inhibitory potency is mainly regulated by the variation of some reactivity indices of atoms 24 (ring D) and 5 (ring B). The action mechanism is mostly orbital-controlled, but also has steric control through the orientational parameter $\varphi_{8}$. If we carry out a variable-by-variable analysis $(\mathrm{VbV}$, that is not fully correct but may shed some light onto the inhibitory mechanism; this method is analogous to the also not fully correct substituent-by-substituent analysis found in almost all medicinal chemistry journals) we may say that a good inhibitory capacity is associated with a positive net charge on atom 5 (that is compatible with a low Fukui index for the highest occupied MO located on this atom, $\mathrm{HOMO}^{*}$ ) and with the requirement that the molecular HOMO and HOMO-1 be located at atom 24 (see Figure 1 for atom numbering). The appearance of atom 5 could indicate that rings $\mathrm{A}$ and $\mathrm{B}$ are interacting 
through $\pi$ stacking with an aromatic counterpart in the enzyme molecule. In fact, this is the same suggestion made by Chen et al. after analyzing the X-ray structure of molecule 41 bonded to HCV NS5B polymerase ${ }^{40}$ (note that the frozen X-ray structure of NS5B is not necessarily the same as the biologically active conformation). Atom 17 should have an empty MO located on it, this being the best situation when part of the molecular LUMO is located on atom 17 (i.e., $\mathrm{LUMO}=\mathrm{LUMO}_{7}{ }^{*}$ ) and should act as an electron receptor area when interacting with the enzyme. This is coherent with the fact that the carbonyl O atom attached to atom 17 decreased its electron population. Then an optimal substituent $R_{1}$ would be one helping to diminish the electron density on atom 17 . Atom 12 is involved as an electron-accepting center. The orientational factor $\varphi_{8}$ indicates that an optimal substituent should be small enough to regulate the rotation of the molecule about the principal axis of rotation. Nevertheless the following example will show that we must be very careful with the use and meaning of orientational factors. Let us consider a series of molecules in which atom $\mathrm{x}$ was substituted with alkyl chains (ethyl, n-propyl, n-hexyl, etc.) and that the resulting QSAR equation suggests that a small substituent will be optimal. In this case, if the original set does not contain the methyl substituent, the correct choice is to use it for testing because its effects on the electronic structure of the rest of the system are similar to the other alkyl substituents. It is erroneous to suggest replacing alkyl chains by, for example, a fluorine atom, because its effect is entirely different (and is quite strong if attached to aromatic systems). In our case, the suggestion that a fluorine atom is the optimal substituent is reasonable because our set includes a fluorine atom attached to atom 23. Figure 2, spanning three orders of magnitude, shows that there is a good correlation of observed versus calculated values and that almost all points are inside the $95 \%$ confidence interval. As the $\mathrm{IC}_{50}$ values are technically binding affinity constants the good results obtained here corroborate that the master equation works very well for these kinds of systems ${ }^{48,56-60,65-68,70}$. The possibility that rings $\mathrm{A}$ and $\mathrm{B}$ participate in a cation- $\pi$ interaction cannot be discarded $^{82}$. Figure 8 depicts parts of the 2D inhibitory pharmacophore.

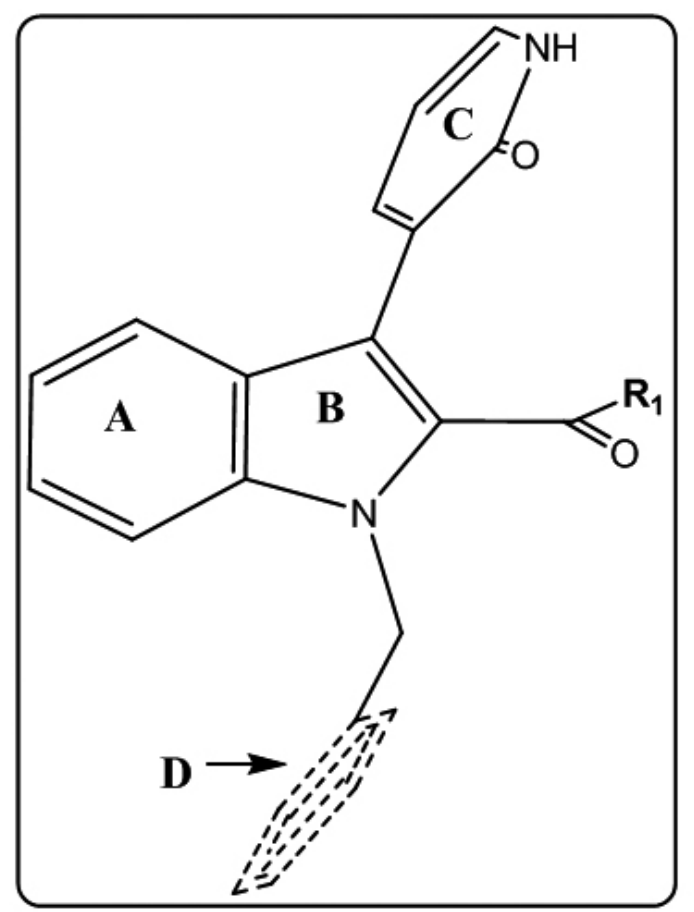

Figure 7. Three-dimensional arrangement of rings A-B, C and D.

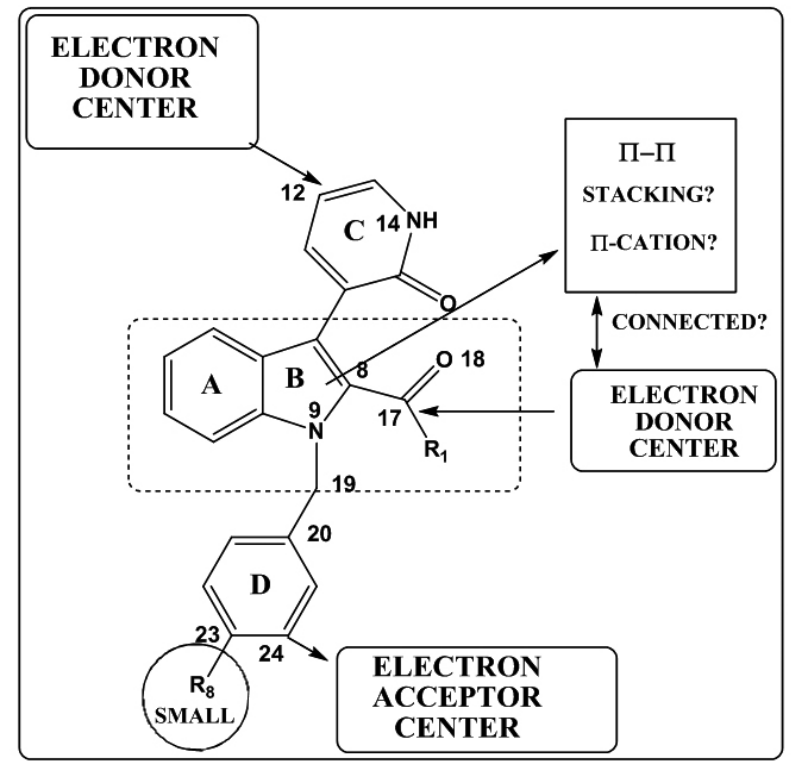

Figure 8. Partial 2D pharmacophore for RdRp (RNA-dependent RNA polymerase) results for set I from Eq. 6 .

Analysis of the inhibitory potency measured by the cell-based replicon assay for set I (reversible inhibitors).

Analysis of Eq. 7 and the Beta coefficients of Table 4 shows that the variation of the inhibitory potency is mainly regulated by the variation the hardnesses of atoms 5 (rings A-B) and 14 (ring C), followed by the variation of $F_{12}(L U M O+1) *$ and $F_{22}(H O M O) *$ (see Figure 1 for atom numbering). The whole process is orbital-controlled. The four rings seem to be important in regulating the inhibitory potency. The $\mathrm{VbV}$ analysis suggests that strong inhibition is associated with low values of $\eta_{5}$ and $\eta_{14}$. Remembering that the local atomic hardness of atom $\mathrm{k}$ is the HOMO*-LUMO* gap (i.e., the distance between the highest occupied MO located on atom k and the lowest empty MO located on the same atom) a low value of this index indicates that atoms 5 and 14 should be prone to modify their electronic density rather easily. In the case of atom 5, which is shared by rings $\mathrm{A}$ and $\mathrm{B}$, it could correspond, as in the case just discussed above, to a $\pi-\pi$ stacking interaction with another aromatic system. In the case of atom 14 (a nitrogen atom) this could be associated with the formation of an $\mathrm{H}$-bond. Atom 12 seems to interact through $(\mathrm{LUMO}+1)^{*}$ and LUMO* with an electron-donating center and atom 22 with an electron-acceptor moiety. Figure 3 shows that several points (at least three) are relatively far from the $95 \%$ confidence interval. This can be explained by suggesting that not all the molecules undergo through the same processes. Also we may consider the possibility that the interaction of some molecules with the biological preparation containing the replicons be different. Unhappily, there is not enough experimental data allowing a more detailed analysis of these suggestions. Note that, due to the free rotation of ring D, position 24 of Figure 8 seems to be the same than position 22 of Fig. 9 . Figure 9 shows parts of the 2D inhibitory pharmacophore.

Analysis of the pharmacokinetic results for set I (reversible inhibitors).

Analysis of Eq. 8 and the Beta coefficients of Table 5 shows that the variation of pharmacokinetic properties is associated with the variation of the electron-acceptor capacity of atoms 6 and 15, the hardness of atom 23 and the electron-donor capacity of atom 25 (see Fig. 1 for atom numbering). The whole process is orbital-controlled. The variables appearing in Eq. 8 belong to all three ring systems. Desirable PK properties are associated with a high $\pi$ electron-acceptor capacity of atom 15 , that may act as such or by facilitating H-bond acceptance by its neighboring O-16. The requirement of atom 6 is that its $(\mathrm{LUMO}+2)^{*}$ localization be low. Given that $(\mathrm{LUMO}+2) *$ is of $\sigma$ nature and (LUMO+1)* and LUMO* are of $\pi$ nature, we may speculate that a low localization of $(\mathrm{LUMO}+2) *$ on atom 6 may facilitate the interaction of $(\mathrm{LUMO}+1)^{*}$ and LUMO* with an electron-donor moiety. The same seems to be the case of atom 25: a low localization of (HOMO-2)* (a $\sigma \mathrm{MO})$ on this atom may facilitate the interaction of (HOMO-1)* and HOMO* (both of $\pi$ nature) with an electron-acceptor area. A high value for the hardness of atom 23 
suggests that this atom or parts of ring D are at some moment of the inhibitor's transport close to an apolar area. Figure 4 shows that almost all the points are inside the $95 \%$ confidence interval. This suggests that, despite of the fact that some these molecules could act in a different way in the cell-based replicon assay, their pharmacokinetic properties are the result of the same processes. Figure 10 shows parts of the 2D pharmacokinetic pharmacophore.

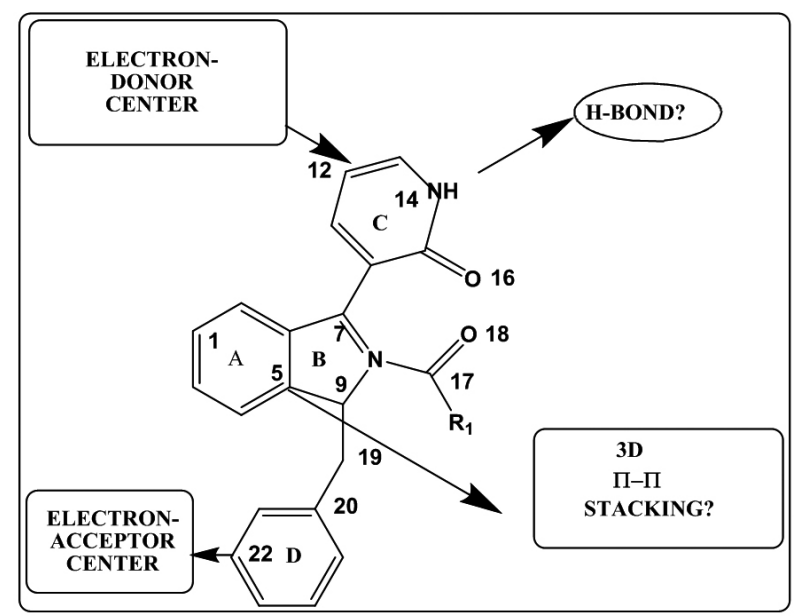

Figure 9. Partial 2D pharmacophore for the cell-based replicon assay results for set I from Eq. 7.

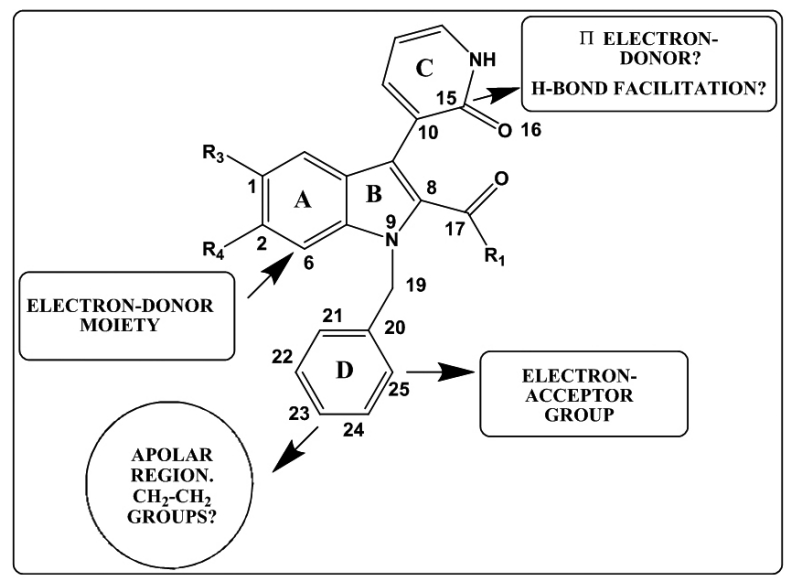

Figure 10. Partial 2D pharmacokinetic pharmacophore for set I from Eq.

Analysis of the RdRp (RNA-dependent RNA polymerase) assay results for Set II (irreversible inhibitors).

Analysis of Eq. 7 and Table 6 indicates that the variation of the inhibitory activity is related to the variation of (in order of importance) $S_{21}{ }^{N}(L U M O+2) *$ $>\varphi_{10}>\varphi_{4} \approx F_{20}(L U M O+2) *>S_{2}{ }^{N}(L U M O) *$ (see Fig. 1 for atom numbering). $\mathrm{A} \mathrm{VbV}$ analysis shows that strong biological activity is correlated with a high value of the nucleophilic superdelocalizability of atom 21 at the $(\mathrm{LUMO}+2)^{*}$ level, low values of $\varphi_{10}$ and $\varphi_{4}$ and a low electron population on (LUMO+2)* of atom 20. Regarding the low values for of $\varphi_{1}$ and $\varphi$, we must insist that, if we intend to test new molecules with smaller substituents at positions 2 and 25 , these substituents must affect the electronic structure of rings $\mathrm{A}$ and $\mathrm{D}$ in the same way as the original ones. The low value for $F_{20}(L U M O+2) *($ a $\sigma \mathrm{MO})$ suggests that atom 20 acts as an electron acceptor through $(\mathrm{LUMO}+1)^{*}$ and (LUMO)* (both of $\pi$ nature). Given that atoms 20 and 21, which are connected, are involved it is possible to suggest that they are probably interacting with a common $\pi$ system of the partner. It is interesting to note that, in the case of the equation for reversible inhibitors, we have local atomic reactivity indices belonging to rings $\mathrm{B}, \mathrm{C}$ and $\mathrm{D}$, while here we have no reactivity indices belonging to ring $\mathrm{C}$. Figure 5 shows for this case that too many points are outside the $95 \%$ confidence interval, fact that can be interpreted by suggesting that we are in presence of at least two different action mechanisms such as reversible and irreversible binding. Also, these differences could be due because of extra interactions occurring directly through a substituent. Figure 11 shows parts of the 2D inhibitory pharmacophore for set II from Eq. 7.

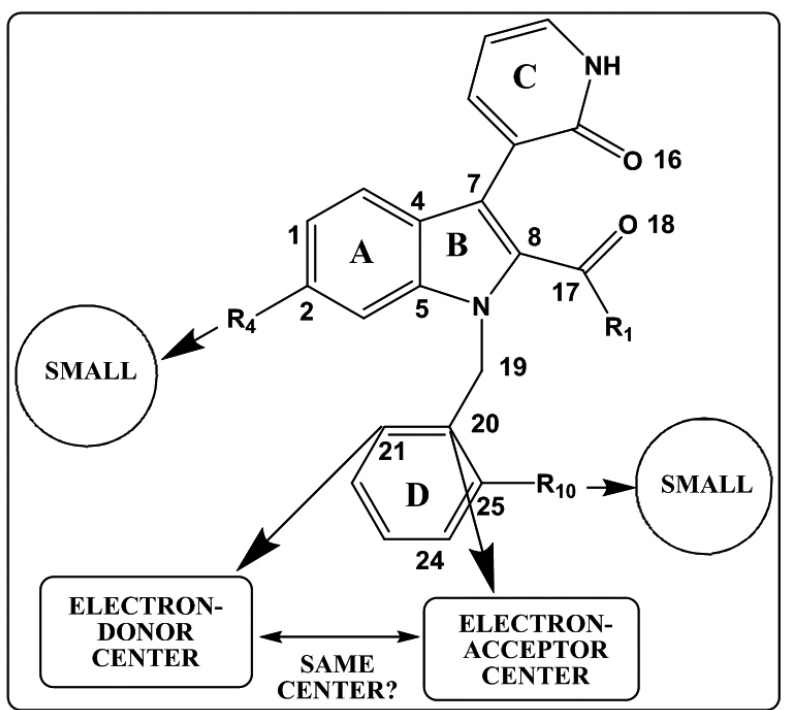

Figure 11. Partial 2D inhibitory pharmacophore (RdRp assay) for set II from Eq. 9.

Analysis of the inhibitory potency measured by the cell-based replicon assay for set II (irreversible inhibitors).

Analysis of Eq. 10 and Table 7 indicates that the variation of the inhibitory activity is related to the variation of (in order of importance) $\omega_{2}$ $\approx \varphi_{10}>S_{14}{ }^{N}(L U M O+1)^{*}>\varphi_{8}>F_{18}(\text { HOMO }-1)^{*}>S_{13}{ }^{N}>\eta_{11} \approx F_{1}(L U M O+2)^{24}$ $\approx S^{N}(L U M O) *$. The whole process is orbital- and steric-controlled. A VbV analysis shows that strong biological activity is correlated with a high value for $\omega_{24}$. This local atomic reactivity index includes the tendency of the electrophile atom to receive extra electronic charge together with its resistance to exchange charge with the medium. Remembering that $\omega$, values must be equal to or greater than zero and that $\omega_{i}=\mu_{i}^{2} / \eta_{i}$, a high value of $\omega_{i}$ could be associated with a low value for $\eta_{i}$, which means a small HOMO*-LUMO* gap. If extra charge is received, the optimal situation occurs when LUMO $*=$ LUMO. Low values for the orientational parameters $\varphi_{10}$ and $\varphi_{8}$ indicate that small substituents at positions 23 and 25 will be optimal for the correct alignment of the drug molecule. A high value for $\eta_{l l}$ suggests that part of ring $\mathrm{C}$ is close to an apolar area. A high value for $F_{(H O M O-1)}$ * suggests the probable participation of oxygen 18 in a hydrogen bond. A low value for $S_{14}{ }^{N}(L U M O+1) *$ can be interpreted as a possible $\mathrm{N}-\mathrm{H} . . \mathrm{X}$ bond in which atom $\mathrm{X}$ is more electronegative than the nitrogen atom. Atom 13 seems to interact with an electron-donor moiety. We shall refrain from analyzing what the participation of atom 1 is because we cannot provide a clear and satisfactory explanation at this moment. Note that atoms 21 or 24 appear also in Eqs. 6 and 9. Figure 6 shows that almost all points are inside or very close to the $95 \%$ confidence interval. This is a good indication that the inhibitory potency is regulated by the electronic structure of the common skeleton and that all molecules act in a similar way. Figure 12 shows parts of the 2D inhibitory pharmacophore for set II from Eq. 10.

\section{CONCLUSIONS}

We have obtained statistically significant QSAR equations for two groups of indole- based molecules relating their molecular/electronic structure to their inhibitory potencies vs. HCV NS5B polymerase and in a cellular replicon assay. The action mechanisms seem to be different for reversible and irreversible inhibitors. It was also possible to find a relationship between structure and pharmacokinetic profile. The new local atomic reactivity indices, coming from conceptual density functional theory and introduced recently by us in QSAR studies, have shown their utility. It is important to stress that one of them, the local atomic hardness, seems to give a good account of the interaction of the drugs with apolar sites (for example methylene groups of amino acid chains) of 
the partner (enzyme, receptor, etc.). A very important and general conclusion is that the method used here is adequate, opening the door to analyze with Quantum Chemistry any in vitro or in vivo measurement of biological activity. The only limitation of the model is that, for multistep processes, the various variables appearing in the QSAR equations cannot be assigned to a particular step. The only exception is the molecule-site equilibrium constant.

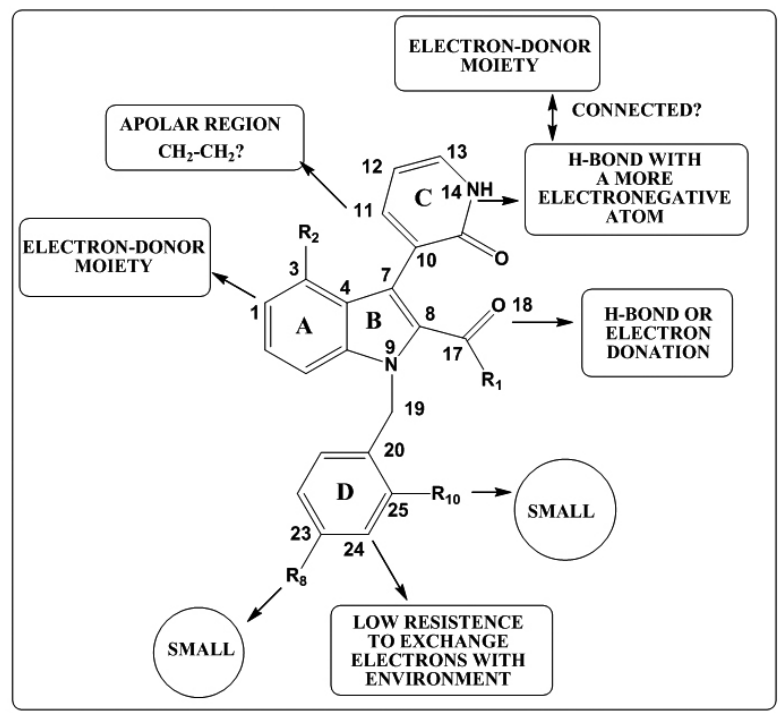

Figure 12. Partial 2D inhibitory pharmacophore (replicon assay) for set II from Eq. 10.

\section{ACKNOWLEDGEMENTS}

This paper is dedicated to the memory of Prof. Dr. Guillermo Contreas Koder, a good scientist and a fine man.

\section{REFERENCES}

1. W.H.O. (WHO), Fact sheet $N^{\circ} 164$, (July 2012).

2. H. Wang, Z. Yuan, E. Barnes, M. Yuan, C. Li, Y. Fu, X. Xia, G. Li, P.N. Newton, M. Vongsouvath, P. Klenerman, O.G. Pybus, D. Murphy, K. Abe, L. Lu, J. Gen. Virol., 94, 76, (2013).

3. I. Romero-Brey, A. Merz, A. Chiramel, J.Y. Lee, P. Chlanda, U. Haselman, R. Santarella-Mellwig, A. Habermann, S. Hoppe, S. Kallis, P. Walther, C. Antony, J. Krijnse-Locker, R. Bartenschlager, PLoS Pathogens, 8, (2012).

4. R.T. Mosley, T.E. Edwards, E. Murakami, A.M. Lam, R.L. Grice, J. Du, M.J. Sofia, P.A. Furman, M.J. Ottoa, J. Virol., 86, 6503, (2012).

5. L. Kong, E. Giang, T. Nieusma, J.B. Robbins, M.C. Deller, R.L. Stanfield, I.A. Wilson, M. Law, J. Virol., 86, 13085, (2012).

6. S. Feuerstein, Z. Solyom, A. Aladag, A. Favier, M. Schwarten, S Hoffmann, D. Willbold, B. Brutscher, J. Mol. Biol., 420, 310, (2012).

7. T. Whitfield, A.J. Miles, J.C. Scheinost, J. Offer, P. Wentworth Jr, R.A. Dwek, B.A. Wallace, P.C. Biggin, N. Zitzmann, Mol. Memb. Biol., 28, 254, (2011)

8. M. Schmitt, N. Scrima, D. Radujkovic, C. Caillet-Saguy, P.C. Simister, P. Friebe, O. Wicht, R. Klein, R. Bartenschlager, V. Lohmann, S. Bressanelli, J. Virol., 85, 2565, (2011).

9. M. Rychłowska, A.M. Owsianka, S.K.H. Foung, J. Dubuisson, K Bieńkowska-Szewczyk, A.H. Patel, J. Gen. Virol., 92, 2249, (2011).

10. S.C. Chan, S.Y. Lo, J.W. Liou, M.C. Lin, C.L. Syu, M.J. Lai, Y.C. Chen, H.C. Li, Biochem. Biophys. Res. Comm., 404, 574, (2011).

11. J. Ouellet, S. Melcher, A. Iqbal, Y. Ding, D.M.J. Lilley, RNA, 16, 1597, (2010).

12. S. Malancona, M. Donghi, M. Ferrara, J.I. Martin Hernando, M. Pompei, S. Pesci, J.M. Ontoria, U. Koch, M. Rowley, V. Summa, Biorg. Med. Chem., 18, 2836, (2010).

13. H. Kanamori, K. Yuhashi, S. Ohnishi, K. Koike, T. Kodama, J. Gen. Virol., 91, 1207, (2010).

14. P. Friebe, R. Bartenschlager, J. Virol., 83, 11989, (2009).
15. J.B. Duvignaud, C. Savard, R. Fromentin, N. Majeau, D. Leclerc, S.M. Gagné, Biochem. Biophys. Res. Comm., 378, 27, (2009).

16. I.C. Lorenz, J. Marcotrigiano, T.G. Dentzer, C.M. Rice, Nature, 442, 831, (2006).

17. L. Krekulová, V. Řehák, L.W. Riley, Fol. Microbiol., 51, 665, (2006).

18. B.K. Biswal, M.M. Cherney, M. Wang, L. Chan, C.G. Yannopoulos, D. Bilimoria, O. Nicolas, J. Bedard, M.N.G. James, J. Biol. Chem., 280, 18202, (2005).

19. A. Tuplin, D.J. Evans, P. Simmonds, J. Gen. Virol., 85, 3037, (2004).

20. R. Ménez, M. Bossus, B.H. Muller, G. Sibaï, P. Dalbon, F. Ducancel, C. Jolivet-Reynaud, E.A. Stura, J. Immunol., 170, 1917, (2003).

21. R. Petracca, F. Falugi, G. Galli, N. Norais, D. Rosa, S. Campagnoli, V. Burgio, E. Di Stasio, B. Giardina, M. Houghton, S. Abrignani, G. Grandi, J. Virol., 74, 4824, (2000).

22. N. Yao, P. Reichert, S.S. Taremi, W.W. Prosise, P.C. Weber, Structure, 7, 1353, (1999).

23. H. Ago, T. Adachi, A. Yoshida, M. Yamamoto, N. Habuka, K. Yatsunami, M. Miyano, Structure, 7, 1417, (1999).

24. K.A. Wong, S. Xu, R. Martin, M.D. Miller, H. Mo, Virology, 429, 57, (2012).

25. F. Velázquez, S. Venkatraman, C.A. Lesburg, J. Duca, S.B. Rosenblum, J.A. Kozlowski, F.G. Njoroge, Org. Lett., 14, 556, (2012).

26. M.J. Sofia, W. Chang, P.A. Furman, R.T. Mosley, B.S. Ross, J. Med. Chem., 55, 2481, (2012).

27. D.B. Nichols, G. Fournet, K.R. Gurukumar, A. Basu, J.C. Lee, N. Sakamoto, F. Kozielski, I. Musmuca, B. Joseph, R. Ragno, N. KaushikBasu, Eur. J. Med. Chem., 49, 191, (2012).

28. D. McGowan, S. Vendeville, T.I. Lin, A. Tahri, L. Hu, M.D. Cummings, K. Amssoms, J.M. Berke, M. Canard, E. Cleiren, P. Dehertogh, S. Last, E. Fransen, E. Van Der Helm, I. Van Den Steen, L. Vijgen, M.C. Rouan, G. Fanning, O. Nyanguile, K. Van Emelen, K. Simmen, P. Raboisson, Biorg. Med. Chem. Lett., 22, 4431, (2012).

29. V. Martel-Laferrière, D.T. Dieterich, Fut. Virol., 7, 537, (2012).

30. G. Manfroni, F. Meschini, M.L. Barreca, P. Leyssen, A. Samuele, N. Iraci, S. Sabatini, S. Massari, G. Maga, J. Neyts, V. Cecchetti, Biorg. Med. Chem., 20, 866, (2012).

31. D.V. Kumar, R. Rai, K.A. Brameld, J. Riggs, J.R. Somoza, R. Rajagopalan, J.W. Janc, Y.M. Xia, T.L. Ton, H. Hu, I. Lehoux, J.D. Ho, W.B. Young, B. Hart, M.J. Green, Biorg. Med. Chem. Lett., 22, 300, (2012).

32. M.A.H. Ismail, D.A. Abou El Ella, K.A.M. Abouzid, A.H. Mahmoud, Biorg. Med. Chem., 20, 2455, (2012).

33. M.E.D. Francesco, S. Avolio, G. Dessole, U. Koch, M. Pompei, V. Pucci, M. Rowley, V. Summa, Nucleos., Nucleot, Nucl. Acids., 31, 592, (2012).

34. M.E. Di Francesco, S. Avolio, M. Pompei, S. Pesci, E. Monteagudo, V. Pucci, C. Giuliano, F. Fiore, M. Rowley, V. Summa, Biorg. Med. Chem., 20, 4801, (2012).

35. R.R. Deore, G.S. Chen, C.S. Chen, P.T. Chang, M.H. Chuang, T.R. Chern, H.C. Wang, J.W. Chern, Curr. Med. Chem., 19, 613, (2012).

36. R.R. Deore, G.S. Chen, P.T. Chang, T.R. Chern, S.Y. Lai, M.H. Chuang, J.H. Lin, F.L. Kung, C.S. Chen, C.T. Chiou, J.W. Chern, Chem. Med. Chem., 7, 850, (2012).

37. E. Canales, J.S. Carlson, T. Appleby, M. Fenaux, J. Lee, Y. Tian, N. Tirunagari, M. Wong, W.J. Watkins, Biorg. Med. Chem. Lett., 22, 4288, (2012).

38. G.N. Anilkumar, O. Selyutin, S.B. Rosenblum, Q. Zeng, Y. Jiang, T.Y. Chan, H. Pu, L. Wang, F. Bennett, K.X. Chen, C.A. Lesburg, J. Duca, S. Gavalas, Y. Huang, P. Pinto, M. Sannigrahi, F. Velazquez, S. Venkatraman, B. Vibulbhan, S. Agrawal, E. Ferrari, C.K. Jiang, H.C. Huang, N.Y. Shih, F. George Njoroge, J.A. Kozlowski, Biorg. Med. Chem. Lett., 22, 713, (2012).

39. K.X. Chen, C.A. Lesburg, B. Vibulbhan, W. Yang, T.Y. Chan, S. Venkatraman, F. Velazquez, Q. Zeng, F. Bennett, G.N. Anilkumar, J. Duca, Y. Jiang, P. Pinto, L. Wang, Y. Huang, O. Selyutin, S. Gavalas, H. Pu, S. Agrawal, B. Feld, H.C. Huang, C. Li, K.C. Cheng, N.Y. Shih, J.A. Kozlowski, S.B. Rosenblum, F.G. Njoroge, J. Med. Chem., 55, 2089, (2012).

40. K.X. Chen, B. Vibulbhan, W. Yang, M. Sannigrahi, F. Velazquez, T.Y. Chan, S. Venkatraman, G.N. Anilkumar, Q. Zeng, F. Bennet, Y. Jiang, C.A. Lesburg, J. Duca, P. Pinto, S. Gavalas, Y. Huang, W. Wu, O. Selyutin, S. Agrawal, B. Feld, H.C. Huang, C. Li, K.C. Cheng, N.Y. Shih, J.A. Kozlowski, S.B. Rosenblum, F.G. Njoroge, J. Med. Chem., 55, 754, (2012).

41. D. Agin, L. Hersh, D. Holtzman, Proc. Nat. Acad. Sci. (USA), 53, 952, 
(1965).

42. A. Cammarata, J. Med. Chem., 11, 1111, (1968).

43. A. Cammarata, R.L. Stein, J. Med. Chem., 11, 829, (1968).

44. A. Cammarata, S.J. Yau, J. Med. Chem., 13, 93, (1970).

45. F. Peradejordi, A.N. Martin, A. Cammarata, J. Pharm. Sci., 60, 576, (1971).

46. J.S. Gómez-Jeria, Int. J. Quant. Chem., 23, 1969, (1983).

47. J.S. Gómez-Jeria, "Modeling the Drug-Receptor Interaction in Quantum Pharmacology," in Molecules in Physics, Chemistry, and Biology, J. Maruani Ed., vol. 4, pp. 215, Springer Netherlands, 1989.

48. J.S. Gómez-Jeria, M. Ojeda-Vergara, C. Donoso-Espinoza, Mol. Engn., 5, 391, (1995).

49. J.S. Gómez-Jeria, M. Ojeda-Vergara, J. Chil. Chem. Soc., 48, 119, (2003).

50. J.S. Gómez-Jeria, Elements of Molecular Electronic Pharmacology (in Spanish), Ediciones Sokar, Santiago de Chile, 2013.

51. J.S. Gómez-Jeria, Canad. Chem. Trans., 1, 25, (2013).

52. R.F. Hudson, G. Klopman, Tet. Lett., 8, 1103, (1967).

53. G. Klopman, R.F. Hudson, Theoret. Chim. Acta, 8, 165, (1967).

54. G. Klopman, J. Am. Chem. Soc., 90, 223, (1968).

55. K. Fukui, H. Fujimoto, Frontier orbitals and reaction paths: selected papers of Kenichi Fukui, World Scientific, Singapore; River Edge, N.J., 1997.

56. J.S. Gómez-Jeria, D. Morales-Lagos, "The mode of binding of phenylalkylamines to the Serotonergic Receptor," in QSAR in design of Bioactive Drugs, M. Kuchar Ed., pp. 145, Prous, J.R., Barcelona, Spain, 1984.

57. J.S. Gómez-Jeria, D.R. Morales-Lagos, J. Pharm. Sci., 73, 1725, (1984)

58. J.S. Gómez-Jeria, P. Sotomayor, J. Mol. Str. (Theochem), 166, 493, (1988).

59. J.S. Gómez-Jeria, L. Lagos-Arancibia, Int. J. Quant. Chem., 71, 505, (1999).

60. J.S. Gómez-Jeria, L. Lagos-Arancibia, E. Sobarzo-Sánchez, Bol. Soc. Chil. Quim., 48, 61, (2003).

61. J.S. Gómez-Jeria, F. Soto-Morales, G. Larenas-Gutierrez, Ir. Int. J. Sci., 4, 151, (2003).
62. J.S. Gómez-Jeria, L.A. Gerli-Candia, S.M. Hurtado, J. Chil. Chem. Soc., 49, 307, (2004).

63. F. Soto-Morales, J.S. Gómez-Jeria, J. Chil. Chem. Soc., 52, 1214, (2007).

64. J.S. Gómez-Jeria, F. Soto-Morales, J. Rivas, A. Sotomayor, J. Chil. Chem. Soc., 53, 1393, (2008).

65. J.S. Gómez-Jeria, J. Chil. Chem. Soc., 55, 381, (2010).

66. F. Salgado-Valdés, J.S. Gómez-Jeria, J. Quant. Chem., in press., (2013).

67. J.S. Gómez-Jeria, D. Morales-Lagos, J.I. Rodriguez-Gatica, J.C. Saavedra-Aguilar, Int. J. Quant. Chem., 28, 421, (1985).

68. J.S. Gómez-Jeria, D. Morales-Lagos, B.K. Cassels, J.C. SaavedraAguilar, Quant. Struct.-Relat., 5, 153, (1986).

69. J.S. Gómez-Jeria, B.K. Cassels, J.C. Saavedra-Aguilar, Eur. J. Med Chem., 22, 433, (1987)

70. J.S. Gómez-Jeria, M. Ojeda-Vergara, Int. J. Quant. Chem., 61, 997, (1997).

71. F. Tomas, J.M. Aulló, J. Pharm. Sci., 68, 772, (1979).

72. K.S. Rogers, A. Cammarata, Biochem. Biophys. Acta.- Biomemb., 193 22, (1969).

73. K.S. Rogers, A. Cammarata, J. Med. Chem., 12, 692, (1969).

74. A. Cammarata, K.S. Rogers, J. Med. Chem., 14, 269, (1971).

75. J.S. Gómez-Jeria, M. Flores-Catalán, Canad. Chem. Trans., 1, 215, (2013).

76. C. Barahona-Urbina, S. Nuñez-Gonzalez, J.S. Gómez-Jeria, J. Chil. Chem. Soc., 57, 1497, (2012).

77. D.A. Alarcón, F. Gatica-Díaz, J.S. Gómez-Jeria, J. Chil. Chem. Soc., 58, 1651, (2013).

78. E. Ferrari, Z. He, R.E. Palermo, H.-C. Huang, J. Biol. Chem., 283, 33893, (2008).

79. V. Lohmann, F. Körner, J.O. Koch, U. Herian, L. Theilmann, R. Bartenschlager, Science, 285, 110, (1999).

80. F.G. Njoroge, K.X. Chen, N.-Y. Shih, J.J. Piwinski, Acc. Chem. Res., 41, $50,(2008)$.

81. T. Bruna-Larenas, J.S. Gómez-Jeria, Int. J. Med. Chem., 2012 Article ID 682495, 1, (2012).

82. D.A. Dougherty, Acc. Chem. Res., 46, 885, (2012). 